\title{
An Analytic Study on Constructional Relationship of Intrapersonal Factors Fostering Innovation Competency: From Taiwanese Students' Perspectives
}

\author{
Wei-Ting Hsiao ${ }^{1}$, Ming-Chang Wu ${ }^{2}$, Chang-Franw Lee ${ }^{2}$, Wen-Lung Chang ${ }^{3 *}$ \\ ${ }^{1}$ National Yunlin University of Science and Technology/Overseas Chinese University, TAIWAN \\ ${ }^{2}$ National Yunlin University of Science and Technology, TAIWAN \\ ${ }^{3}$ National Academy for Educational Research, TAIWAN
}

Received 29 May 2017 - Revised 9 June 2018 • Accepted 13 July 2018

\begin{abstract}
The objective of this study was to determine the relationship among some intrapersonal factors including individual professional competency, interdisplinary ability, social skills, and team cohesion. Results showed that each of these factors could influence the innovation competency of students enrolled in design programs. To scrutinize effects of these factors on innovation competency, this study examined their correlations with innovation competency and their internal structure in order to comprehensively understand influential processes and paths for innovation competency enhancement in design education. The validated questionnaire was delivered to 296 students enrolled in design programs of universities in Taiwan. SPSS 18.0 and AMOS statistics were used to analyze collected data. To address research questions of this study, t-test, one-way analysis of variance (ANOVA), Pearson correlation analysis, Confirmatory Factor Analysis (CFA), and Structural Equation Modeling (SEM) were performed. The following crucial conclusions were reached: (1) Students enrolled in design programs generally possessed high levels of professional competency, interdisplinary ability, social skills capability, team cohesion, thinking style, and innovation competency; (2) There were significant and positive relationships among these factors. This implies that these intrapersonal factors are highly relied on each other because they co-exist and interact with each other. Thus, any change in one factor would create chain effects; and (3) These highly correlated intrapersonal factors can be developed in real environment through understanding their interactive, hierarchical, and consecutive processes rather than through focusing on effects of a single factor. These conclusions could provide several suggestions for professionals, managers, and, more importantly, school educators in relevant fields. Two suggestions are provided for future high quality and comprehensive research to further understand and improve strategies needed for design education.
\end{abstract}

Keywords: innovation competency, interdisplinary ability, professional competency, social skills capability, team cohesion

\section{BACKGROUND}

With internationalization, Taiwan faces fierce global competition and challenges. The development of various industries has struggled. Accelerating the overall economic transformation and upgrading industries have become top priorities. In this context, cultivating design talents with more innovation competency will aid Taiwan's industrial internationalization $(\mathrm{Wu}$, Chang \& Chen, 2012). What is worthy of concern is whether innovation competency is a personal trait, a natural tendency, or a kind of capacity that can be cultivated and taught. After

(C) 2019 by the authors; licensee Modestum Ltd., UK. This article is an open access article distributed under the terms and conditions of the Creative Commons Attribution License (http://creativecommons.org/licenses/by/4.0/).

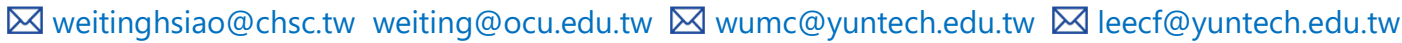




\section{Contribution of this paper to the literature}

- This paper illustrates the importance of social skills, interdisplinary ability, and team cohesion to youngsters' innovation competencies which were conventionally believed being enhanced by professional competencies. In addition, this study approved the successional interaction effects of these factors overwhelm the single-factor effects in the realistic world while people's innovation is inspired. That is, the cultivation of youngsters' innovation ability needs systematic contribution of contextual factors, including both personal and environmental elements, rather than any single reform.

years of systematic research in academic circles, scholars no longer regard innovation competency as an inspired passage. Instead, scholars emphasize effects of skill cultivation and social environmental factors, making innovation competency something that can be affected, taught, and changed in nature (Craft, Jeffrey \& Leibling, 2001; Jeffrey \& Craft, 2004). With this in mind, previous studies have explored the effect of interaction between an individual and his environment on innovation competency (Amabile, Conti, Lazenby \& Herron, 1996; Bandura, 2001) and determined influencing factors at individual level such as personality traits (Chen, 2005), ability requirements (Kerr \& Gagliardi, 2003), or achievement motivation (Basadur \& Hausdorf, 1996). An analysis of these issues will help us understand the nature of innovation competency and its internal structure as well as hierarchical effects of mutual influences among various factors.

\section{Research Purpose}

The purpose of this study was to explore characteristics of innovation competency of students enrolled in design programs and understand the internal structure of innovation competency and mutual influences among various factors by analyzing performance characteristics of each dimension.

\section{Research Questions}

Based on our analysis and discussion, we have the following research questions:

(1) What are characteristics of innovation competency of students enrolled in design programs?

(2) What characteristics can be inferred from correlations among four factors of innovation competency?

(3) What are characteristics of the internal structure among these four factors of innovation competency?

\section{LITERATURE REVIEW}

\section{Capacity Needs in the Design Industry}

Manpower and knowledge in the design industry, like those in many industries, have to be stably upgraded and transformed. Although professional skills taught in design programs of universities/colleges in Taiwan are diversified and specialized, most of them are only focused on specialized areas of design. Beside design expertise, design services also need operational professionals in related areas such as finance, planning, marketing, and so on to handle, manage, and maintain a company's needs. Past studies have found that design professionals should have conceptual, technical, communication, integration, and adaptation ability with background knowledge and professional attitude (Stark, Lowther, \& Hagerty, 1986). Based on this, it is evident that quality facets of designers discussed in past studies are diversified. Considerable importance has been attached to conditions under which design professionals can achieve high success ( $\mathrm{Lu} \& \mathrm{Lu}, 2012)$. However, these studies did not expound on which abilities are constructive factors of innovation competency. Therefore, the present study will focus on constructive factors underpinning the innovation competency of students enrolled in design programs and explore how professional competency of students enrolled in design programs can influence their innovation competency and thus improve the efficiency and correlation through factors of interdisplinary ability, social skills, and team cohesion.

\section{Definition and Connotation of Innovation Competency}

\section{Definition of innovation competency}

What is innovation? Economics master Joseph A. Schumpeter has defined innovation as "developing things that have been invented into activities socially acceptable and of commercial value". Management master Peter Drucker (1998) has also argued that "innovation is the new ability empowering resources and creating wealth. Increasing the value of original resources is exactly innovation." Robins (2001) has argued that innovation 
competency is a kind of change and a new thinking that can improve products, processes, or services. Janssen (2003) has believed that innovation competency is the overall innovation behavior related to creativity and innovation. It is exhibited by members of an organization in the workplace. It is also a complex behavior with three different behavioral tasks, namely creative formation, creative promotion, and creative realization. Wen and Chen (2008) have thought that innovation competency is a means that allows an organization to enhance its competitiveness. It is also a course through which employees attempt to put creative ideas generated from brainstorming into practice based on interests of individuals and the organization. Integrating perspectives of these scholars, this study defines innovation competency considering the following aspects. The meaning of innovation is a high-value thinking belief that help people generate positive and optimistic beliefs. The goal of innovation is to improve and enhance the quality of an organization. The process of innovation is a process of transforming abstract and new ideas into concrete and feasible actions. In other words, any new idea, method, or product that can be proposed or made can be called an "innovation". Innovation competency explored in this study targets an individual's behavior change ability caused by combined effects of personal traits, cognitive ability, and social environment.

\section{Connotation of innovation competency}

The concept of innovation was first proposed by Schumpeter in the 1930s. It originated from the Latin word "Novus". Its original meaning refers to introducing something or a new concept (Robins, 2001). According to Robbins (2001), connotation of innovation is "the process of adopting new ideas and transforming them into useful products, services, or technologies." Therefore, innovation means that individuals or organizations adopt new ideas and implement them. Scott and Burce (1994) have put forward three dimensions of personal innovation behavior, namely generation of innovative ideas, promotion of innovative ideas, and realization of innovative ideas.

Dimensions of innovation competency adopted in this study follow those developed by Scott and Burce (1994). The measuring instrument used in this study was slightly adapted from the scale revised by Janssen (2003) and developed further by Tian and Lu (2005) for "innovative behavior" in the workplace. The instrument contained a total number of 10 questions distributed across three dimensions: 3 questions for idea generation, 3 questions for idea promotion, and 4 questions for idea realization. Cronbach's a coefficient of this scale was found to be 0.91 .

\section{Relationships among Innovation Competency, Professional Competency, Interdisplinary Ability, Social Skills Capability, and Team Cohesion}

Innovation competency is mainly the result of an interaction between professional proficiency and the good use of creative skill in a specific field (Amabile et al., 1996). Specifically, innovation competency is influenced by professional knowledge in the field (Hung, Chen, \& Yeh, 2006). Therefore, innovation is based on deep professional knowledge and technical ability (Chen \& Huang, 2006).

In the past, innovation had long been seen as being developed only within an individual. However, now it is generally understood that interdisplinary access to external knowledge is needed in order to achieve the goal of innovation (Calantone \& Stanko, 2007). That is, an individual's interdisplinary practice can enhance innovation competency (Hagel \& Brown, 2005). From the perspective of enterprise, companies should make good use of employees or supervisors with good personality traits, encourage them to carry out interdisplinary learning, and cultivate them into good tools for enterprise innovation. Today, this is a very important management issue (Fagerberg, Mowery \& Nelson, 2005; Kimble, Grenier \& Goglio-Primard, 2010). Past studies (Kodama, 2007, 2009; Teigland \& Wasko, 2003) have found that interdisplinary teams can integrate multiple skills, knowledge, and experience, making the team's capability more influential than the individual's capacity. They can even avoid the group myth issue regarding group decisions being easily formed in a team with homogeneous members. The argument that diversified and heterogeneous interdisplinary behaviors resulting from different occupations and different industries and innovations brought by interdisplinary knowledge flow can enhance organizational capabilities has received considerable support from studies by various scholars (Kimble et al., 2010).

When an individual is operating in a team-working environment, interpersonal skills become more important (Cohen, 1995). This ability can also be called social skills, including social interaction, cooperation, persuasion, negotiation, guidance, and helping others (Morgeson, Reider \& Campionk, 2005). If individuals have better communication, listening, and interactive skills, then the organization will be able to increase possibilities available for adding new knowledge and obtaining new ideas through social interaction to share team experiences and knowledge (Hulsheger, Anderson \& Salgado, 2009). Thus, enhancing social skills is the key to accumulation of intellectual capital nowadays (Hsiao \& Lai, 2010).

From the preceding section, it can be asserted that innovation competency is influenced by professional competency, interdisplinary capability, social skills or capability, and individuals' mentality toward team cohesion in an organization. In particular, when facing an environment full of uncertainty in corporate practice, team 


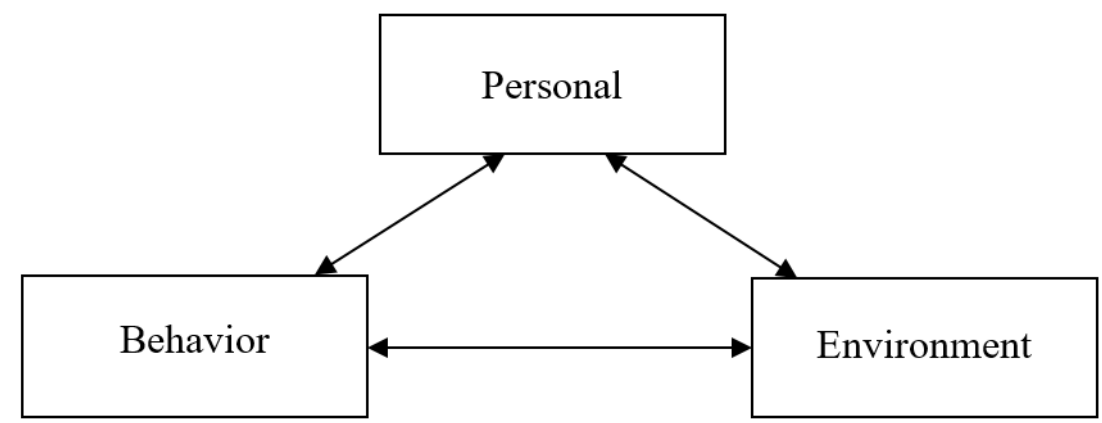

Figure 1. Model of triadical reciprocality (Bandura, 1997)

cohesion is needed to integrate talents from various professional fields and cope with this complex environment full of variables (Cefis \& Marsili, 2006).

\section{Comprehensive Reflection of Literature Analysis}

\section{Importance of design talents}

The fact that Taiwan's industrial scale coupled with high global business competition is very different from other developed countries means that enterprises that can understand consumers' needs and connect with them through excellent R\&Ds and innovations will be able to protect themselves and further their interests (Ay \& Sung, 2010). Because design can affect the ultimate mentality of consumers, under the current situation where Taiwan's industries urgently need transformation, innovation has become a new magical weapon for business survival while designers or creative individuals have frequently become targets of enterprises that seek to take advantage of their talents.

\section{Innovation competency is the main connotation of design talent cultivation}

Based on a survey conducted by Professor Wang (2014) of National Taiwan Normal University commissioned by the Ministry of Education, it is evident that a great disparity exists in employment opportunities afforded to students enrolled in design programs. Those who are good are very good and those who are poor are very poor. This is greatly related to advantages and disadvantages that accrue from an individual's innovation competency (Wang, Chang, \& Chiang, 2014). This also highlights that innovation competency courses or related courses developed for students in university design programs will be a critical factor for cultivating design talents with more innovation competency in Taiwan and enhancing national competitiveness (Wu et al., 2012).

\section{Factors enhancing benefits of innovation competency}

Early research in the field of creative ideas have placed a lot of emphasis on creativity or the creator's own traits (professional competency, personality traits, etc.) by forcing out and extracting creative ideas through personal traits. Later research studies have attempted to explore the kind of external environment helpful (or unhelpful) for generating creative ideas. That is, a social interaction point of view underlies various investigations (Amabile, 1988, 1996). Previous researches have regarded creative idea as the product of social interaction (Woodman et al., 1993), focusing on the interaction among various variables, including organizational characteristics, social factors, and individual traits. Thus, innovation was regardes as an activity developed only within an individual or organization in the past. However, now it is generally understood that the goal of innovation can only be achieved through team cohesion (Chesbrough \& Crowther, 2006).

Social cognition theory (Bandura, 2001) argues that human behaviors and beliefs are often results of continuous interactive influences among personal, behavioral, and environmental factors (Figure 1). From this, it can be asserted that the development and playing out of an individual's ability are not affected by a single factor. They often continuously evolve and develop in the interaction process of several possible factors. In the process of interaction and exchange, benefits of individual factors may change, transform, or even disappear (Bandura, 1989).

This study therefore takes the view of reciprocal determinism as it plays out in the social learning theory of Albert Bandura (2001) and the view of social interaction as it plays out in the creativity theory of Amabile et al. (1996) to further explore how professional competency and innovation competency of design students are cultivated through intrapersonal factors such as their interdisplinary ability, social skills, and team cohesion. In 


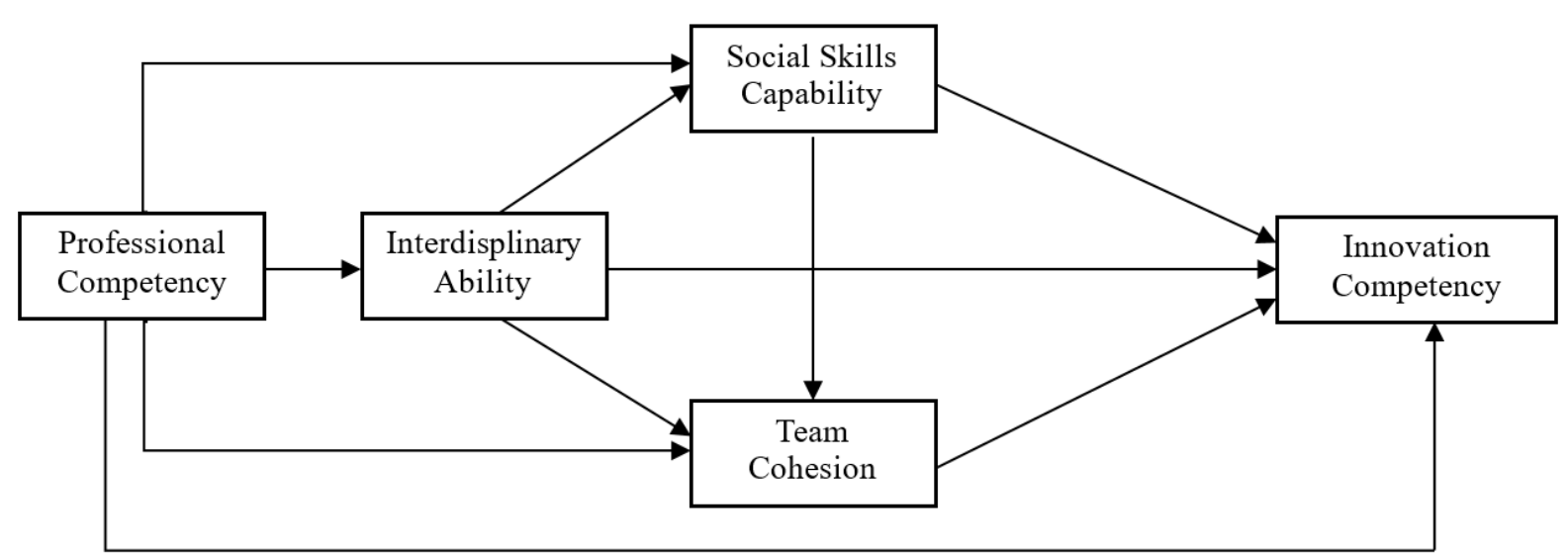

Figure 2. Research framework

Table 1. Basic data summary of formal questionnaire sample $(N=296)$

\begin{tabular}{lcc}
\hline Basic Data of Subjects & Number of Subjects (N) & Percentage (\%) \\
\hline University Enrolled & & \\
\hline Public University & 192 & $64.9 \%$ \\
\hline Private University & 104 & $35.1 \%$ \\
\hline Gender & & $30.7 \%$ \\
\hline Male & 91 & $69.3 \%$ \\
\hline Female & 205 & \\
\hline Program & & $4.7 \%$ \\
\hline Space Design & 14 & $32.8 \%$ \\
\hline Product Design & 97 & $39.2 \%$ \\
\hline Visual Communication & 116 & $21.3 \%$ \\
\hline Integrated Design & 63 & $2.0 \%$ \\
\hline Other & 6 & $100 \%$ \\
\hline Total & 296 & \\
\hline
\end{tabular}

addition, this study pays attention to correlational structure among these five constructs and uses it to conduct an in-depth analysis of interactive influences and structural relationships among them.

\section{RESEARCH METHOD}

\section{Research Framework}

The purpose of this study was to explore characteristics of innovation competency of students enrolled in design programs and analyze internal structural relationships among these constituent factors (Figure 2).

\section{Research Objects}

This study was conducted with purposive sampling. Students enrolled in design programs of five universities/colleges located in northern, middle, and southern Taiwan in 2016 academic year were sampled. With respect to research instrument, a total of 400 questionnaires were distributed and 324 valid questionnaires were collected. The total number of valid questionnaires was 296 after excluding questionnaires with incomplete information. Thus, the recovery rate was $81 \%$ and the usability rate was $74 \%$. These students categorized by gender and program were basically consistent with proportions enrolled in higher education institutions of Taiwan. Female students dominated these Design Schools. Visual Communication had the most number of students while Space Design had the least number of students. These subjects' basic data are summarized in Table 1.

\section{Research Tools}

This study mainly used questionnaire survey method. The survey comprised six parts: basic personal data, design professional competency, interdisplinary ability, social skills capability, team cohesion, and innovation competency. The questionnaire was prepared and developed by using modified five-point Likert scoring method. Most questions included in the measuring tool were derived from existing scales. For example, the professional 
Table 2. Results of reliability and validity analysis of various scales of a formal questionnaire $(N=296)$

\begin{tabular}{|c|c|c|c|c|c|c|}
\hline Potential Variable & Subdimension & Number of Questions & Factor Loading & Cronbach's $\alpha$ & CR & AVE \\
\hline \multirow[t]{6}{*}{ Professional Competency } & & 29 & $.631 \sim .882$ & 0.950 & 0.8697 & 0.5746 \\
\hline & Design Literacy & 7 & $.634 \sim .787$ & 0.860 & 0.8842 & 0.5231 \\
\hline & Design Theory & 5 & $.672 \sim .815$ & 0.896 & 0.8768 & 0.5885 \\
\hline & Operational Practice & 5 & $.560 \sim .841$ & 0.863 & 0.8394 & 0.5174 \\
\hline & Design Application & 5 & $.694 \sim .791$ & 0.879 & 0.8679 & 0.5684 \\
\hline & Design Planning & 7 & $.640 \sim .846$ & 0.917 & 0.9017 & 0.5699 \\
\hline Interdisplinary Ability & & 5 & $.731 \sim .910$ & 0.897 & 0.8995 & 0.6435 \\
\hline Social Skills & & 8 & $.551 \sim .746$ & 0.880 & 0.8772 & 0.4738 \\
\hline Team Cohesion & & 5 & $.691 \sim .764$ & 0.849 & 0.8415 & 0.5154 \\
\hline \multirow[t]{4}{*}{ Innovation Competency } & & 9 & $.850 \sim .885$ & 0.923 & 0.9061 & 0.7630 \\
\hline & Innovation Generation & 3 & $.699 \sim .842$ & 0.785 & 0.8179 & 0.6009 \\
\hline & Innovation Promotion & 3 & $.771 \sim .806$ & 0.823 & 0.8276 & 0.6154 \\
\hline & Innovation Realization & 3 & $.754 \sim .857$ & 0.848 & 0.8532 & 0.6601 \\
\hline Overall Scale & & 56 & & 0.965 & & \\
\hline
\end{tabular}

competency subscale utilized the scale proposed by Chiu (2014). For this subscale, there were a total of 34 questions distributed among five dimensions: design literacy, design theory, operational practice, design application, and design planning. Cronbach a coefficient values for all these dimensions were found to be between 0.82 and 0.86 . The interdisplinary ability subscale adopted the interdisciplinary contact dimension scale used in a study of Teigland and Wasko (2003). This subscale comprised 5 questions with a Cronbach a coefficient of 0.919. The subscale of social skills used structured interview to measure social skills used in a study of Morgeson et al. (2005). We modified this subscale into a five-point scale. It comprised a total number of 10 questions with a Cronbach a coefficient of 0.83 . The team cohesion subscale adopted the scale used in a study of Tjosvold (1988). It comprised of 5 questions with a Cronbach a coefficient of 0.935 . The innovation competency subscale utilized the scale used in a study of Janssen (2003). It had a total number of 10 questions distributed across three dimensions, namely idea generation (3 questions), idea promotion (3 questions), and idea realization (4 questions). This scale's Cronbach a coefficient was 0.91 . After applying reliability analysis with expert validity and confirmatory factor analysis (CFA) on a pre-test to check reliability, convergence validity, and discriminant validity of the scale to remove questions that might affect the overall reliability of the scale (5 questions for professional competency, 2 questions for social skills, and 1 question for innovation competency), the remaining 56 questions having sufficient reliability were used to make up the measurement tool of this study.

\section{Analysis of Formal Questionnaire Data}

\section{Reliability analysis}

After performing reliability analysis, the Cronbach a value of the overall scale used in this study was found to be 0.965 and Cronbach a coefficients of all potential variables and sub-dimensions were higher than 0.75 , reaching the high standard for Cronbach a value at 0.7 recommended by scholars (Chiu, 2012). Results of reliability analysis showed that the internal consistency of the questionnaire used in this study was good. It was applicable for empirical research of students enrolled in design programs of Taiwan.

\section{Content validity analysis}

In this study, factor loadings of all observed variables (the five potential variables, including professional competency, social skills, interdisplinary ability, team cohesion, and innovation competency) were greater than 0.5 and the composite reliability (CR) value of all potential variables was greater than 0.6 , indicating that these variables had good credibility. In addition, average variance extraction (AVE) test showed that their average variance extraction values were greater than or close to 0.5 , indicating that they had convergence or aggregation validity (Fornell \& Larcker, 1981). Thus, the internal quality of the measurement model was excellent. Finally, this study conducted an internal consistency reliability analysis on subscales and the overall scale in accordance with the theory proposed by Hair et al. (2010). Results showed that the Cronbach a coefficients of all potential variables and subdimensions were greater than 0.80 with an overall reliability of the scale of 0.965 , demonstrating that the internal consistency of the questionnaire was good. Results are shown in Table 2. Internal quality and external quality of the conceptual model used in this study were good. Thus, it would be suitable for conducting structural model analysis in the next step to verify causal relationships among potential variables. 
Table 3. Performance status analysis results of professional competency, interdisplinary ability, social skills, team cohesion, and innovation competency

\begin{tabular}{ccccc}
\hline Variable Layer & Mean & $\begin{array}{c}\text { Standard } \\
\text { Deviation }\end{array}$ & $\begin{array}{c}\text { Number of } \\
\text { Questions }\end{array}$ & $\begin{array}{c}\text { Mean Score per } \\
\text { Question }\end{array}$ \\
\hline Professional Competency & 105.537 & 15.2310 & 29 & 3.638 \\
\hline Social Skills & 31.016 & 4.4745 & 8 & 3.877 \\
\hline Deviation & 3.319 \\
\hline Interdisplinary Ability & 16.594 & 3.8115 & 5 & 3.788 \\
\hline Innovation Competency & 18.938 & 3.0238 & 5 & 0.5593 \\
\hline
\end{tabular}
$\mathrm{N}=296$

Table 4. Summary table showing the correlation matrix of variables

\begin{tabular}{cccccc}
\hline & Professional & Social Skills & Interdisplinary & Team Cohesion & Innovation \\
\hline Professional & 1 & & & & \\
\hline Social Skills & $.508^{* *}$ & 1 & & \\
\hline Interdisplinary & $.509^{* *}$ & $.455^{* *}$ & 1 & 1 & $.699^{* *}$ \\
\hline Team Cohesion & $.546^{* *}$ & $.765^{* *}$ & $.491^{* *}$ & 1 \\
\hline Innovation & $.642^{* *}$ & $.640^{* *}$ & $.579^{* *}$ & \\
\hline
\end{tabular}

\section{RESEARCH RESULTS}

\section{Results of Performance Status Analysis for Innovation Competency and Four Variables}

Results of this study revealed that current performance characteristics of professional competency, social skills, interdisplinary ability, team cohesion, and innovation competency of students enrolled in design programs were mostly distributed between 3.3 to 3.8. Therefore, they belonged to an above moderate level (Chiu, 2012), as shown in Table 3.

\section{Correlation Analysis of Innovation Competency and Various Factors}

This study used Pearson Product-Moment Correlation Analysis. Results showed that a high and significant correlation existed among the five variables and the performance of any of these variables had a certain influence on the other four variables.

\section{Analysis Results of Effect paths among Dimensions of Innovation Competency - Test of Structural Equation Modeling (SEM)}

\section{Measurement model analysis}

As shown in Table 5, most indexes (GFI, TLI, CFI, AGFI, SRMR, and RMSEA) of the conceptual model and the actual data of these five variables met the standards. Although a small number of goodness of fit indexes did not meet the standards, they were very close to standard values. Therefore, it was judged that the goodness-of-fit of the conceptual model was quite good. Thus, external quality of the measurement model should be consistent with requirements of general academic research. 
Table 5. Measurement model's goodness of fit index checklist

\begin{tabular}{|c|c|c|c|c|c|c|}
\hline $\begin{array}{r}\text { Statisti } \\
\text { (Standa }\end{array}$ & $\begin{array}{l}\text { cal Test } \\
\text { d Value) }\end{array}$ & $\begin{array}{l}\text { Professional } \\
\text { Competency }\end{array}$ & $\begin{array}{c}\text { Social Skills } \\
\text { Capability }\end{array}$ & $\begin{array}{c}\text { Interdisplinary } \\
\text { Ability }\end{array}$ & Team Cohesion & $\begin{array}{c}\text { Innovation } \\
\text { Competency }\end{array}$ \\
\hline \multirow{7}{*}{$\begin{array}{l}\text { Absolute } \\
\text { Goodness of Fit } \\
\text { Index }\end{array}$} & $\begin{array}{c}\chi^{2} \text { (The smaller, } \\
\text { the better) }\end{array}$ & 3468.24 & 387.01 & 65.25 & 225.13 & 320.65 \\
\hline & $\chi^{2} / \mathrm{df}(1 \sim 5)$ & 9.32 & 19.35 & 13.05 & 45.02 & 13.36 \\
\hline & $\operatorname{RMR}(<0.08)$ & $0.046^{*}$ & 0.03 *註 1 & $0.028^{*}$ & $0.029^{\star}$ & $0.024^{*}$ \\
\hline & GFI $(>0.8)^{\text {註2 }}$ & $0.794^{*}$ & $0.895^{*}$ & $0.976^{*}$ & $0.913^{*}$ & $0.929^{*}$ \\
\hline & AGFI $(>0.8)^{\text {註2 }}$ & $0.759 *$ & $0.810^{*}$ & $0.928^{*}$ & 0.739 & $0.868^{*}$ \\
\hline & RMSEA $(<0.08)$ & 0.091 & 0.135 & 0.109 & 0.209 & 0.111 \\
\hline & SRMR $(<0.08)$ & $0.071^{*}$ & $0.055^{\star}$ & $0.03^{*}$ & $0.051^{*}$ & $0.039^{*}$ \\
\hline \multirow{5}{*}{$\begin{array}{l}\text { Incremental } \\
\text { Goodness of Fit } \\
\text { Index }\end{array}$} & $\mathrm{NFI}(>0.9)$ & 0.820 & $0.904^{*}$ & $0.972^{*}$ & $0.912^{*}$ & $0.945^{\star}$ \\
\hline & $\mathrm{TLI}(>0.9)$ & 0.821 & 0.872 & $0.949^{*}$ & 0.827 & $0.924^{*}$ \\
\hline & $\mathrm{RFI}(>0.9)$ & 0.804 & 0.866 & $0.945^{\star}$ & 0.824 & $0.918^{*}$ \\
\hline & IFI $(>0.9)$ & 0.836 & $0.908^{*}$ & $0.974^{*}$ & $0.914^{\star}$ & $0.949^{*}$ \\
\hline & CFI $(>0.9)$ & 0.836 & $0.908^{*}$ & $0.974^{*}$ & $0.914^{*}$ & $0.949^{*}$ \\
\hline \multirow{4}{*}{$\begin{array}{l}\text { Parsimony } \\
\text { Goodness of Fit } \\
\text { Index }\end{array}$} & PNFI $(>0.5)$ & $0.752^{*}$ & $0.646^{*}$ & 0.486 & 0.456 & $0.630^{*}$ \\
\hline & PCFI $(>0.5)$ & $0.766^{*}$ & $0.649 *$ & 0.487 & 0.457 & $0.633^{*}$ \\
\hline & PGFI $(>0.5)$ & $0.679 *$ & 0.497 & 0.325 & 0.304 & 0.496 \\
\hline & $C N(>200)$ & 122 & 83 & 172 & 50 & 115 \\
\hline
\end{tabular}

Note 1: * indicates meeting standard value. Note 2: Hair et al. (2010)

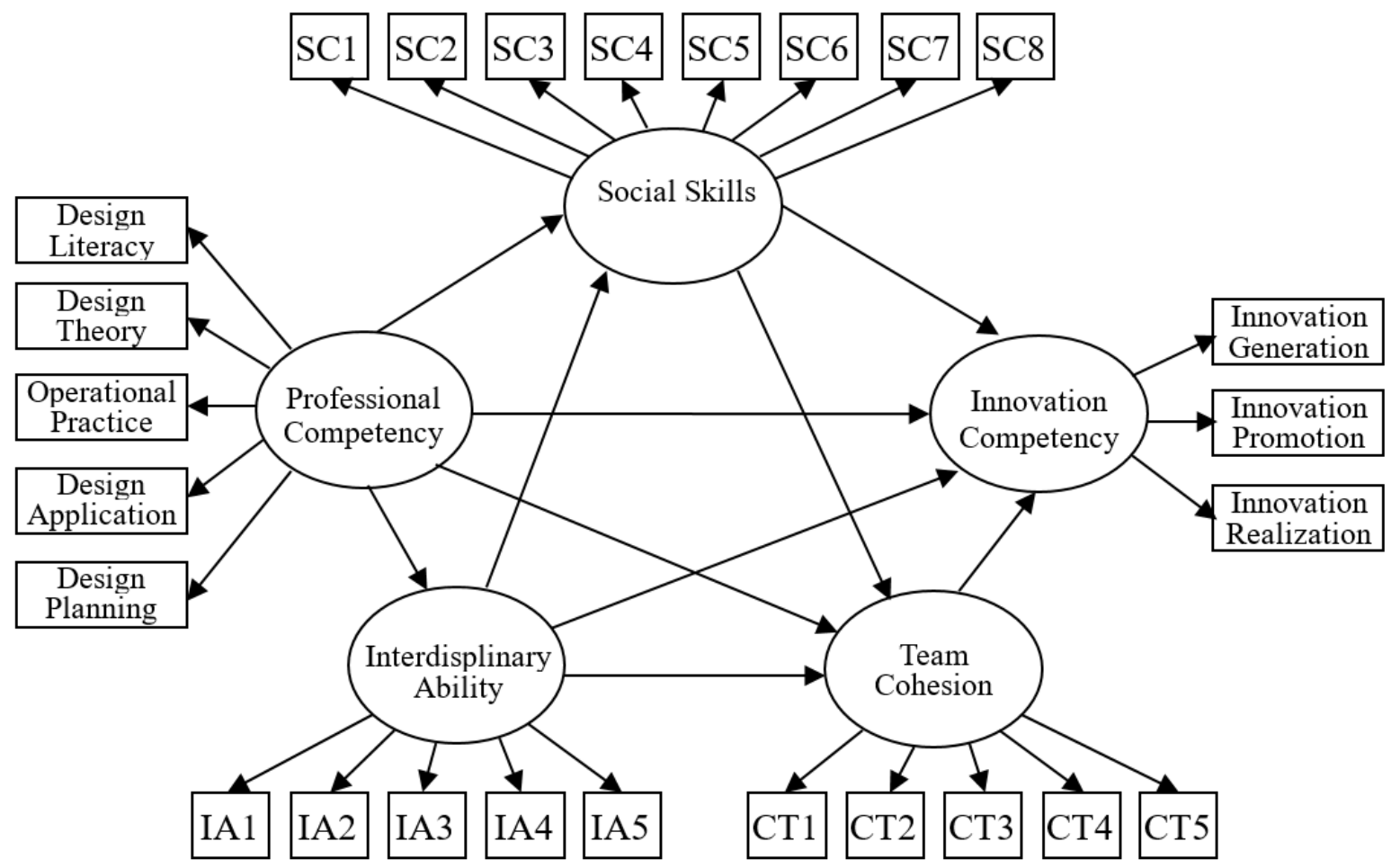

Figure 3. Structural relationship model of five variables

\section{Structural model analysis}

The purpose of this study was to explore the causal model and effect paths as well as structural relationships among the five variables (professional competency, social skills, interdisplinary ability, team cohesion, and innovation competency) with respect to students enrolled in design programs. This study adopted Structural Equation Modeling (SEM) to conduct the analysis (Chiu, 2012). The overall model in five stages (test violation estimate, overall model goodness-of-fit index, model parameter estimation test, hypothesis test, and effect analysis) was evaluated. The overall structural model is shown in Figure 3, including proposed influential paths of these five variables while considering single factor's effects. However, this study focused on identifying synthetic influential paths while interactive effects occurred among study variables. 
Table 6. Overall model goodness-of-fit index checklist

\begin{tabular}{|c|c|c|c|c|}
\hline \multicolumn{2}{|c|}{ Statistical Test } & Standard Value & \multirow{2}{*}{$\begin{array}{l}\text { Test Results } \\
1332.05(286)\end{array}$} & \multirow{2}{*}{$\begin{array}{c}\begin{array}{c}\text { Model Goodness of Fit } \\
\text { Judgment }\end{array} \\
\text { No }\end{array}$} \\
\hline \multirow{7}{*}{$\begin{array}{l}\text { Absolute } \\
\text { Goodness of Fit } \\
\text { Index }\end{array}$} & $\chi^{2}$ & The smaller, the better ( $p \geqq \alpha$ value) & & \\
\hline & $x^{2} / d f$ & Between 1 and 5 (Note 1) & 4.658 & Yes \\
\hline & RMR & Less than 0.08 & 0.026 & Yes \\
\hline & GFI & Greater than 0.8 (Note 2) & 0.903 & Yes \\
\hline & AGFI & Greater than 0.8 (Note 2) & 0.881 & Yes \\
\hline & RMSEA & Less than 0.08 & 0.060 & Yes \\
\hline & SRMR & Less than 0.08 & 0.044 & Yes \\
\hline \multirow{5}{*}{$\begin{array}{l}\text { Incremental } \\
\text { Goodness of Fit } \\
\text { Index }\end{array}$} & $\mathrm{NFI}$ & Greater than 0.9 & 0.922 & Yes \\
\hline & TLI & Greater than 0.9 & 0.929 & Yes \\
\hline & RFI & Greater than 0.9 & 0.911 & Yes \\
\hline & $\mathrm{IFI}$ & Greater than 0.9 & 0.938 & Yes \\
\hline & $\mathrm{CFI}$ & Greater than 0.9 & 0.937 & Yes \\
\hline \multirow{4}{*}{$\begin{array}{l}\text { Parsimony } \\
\text { Goodness of Fit } \\
\text { Index }\end{array}$} & PNFI & Greater than 0.5 & 0.811 & Yes \\
\hline & PCFI & Greater than 0.5 & 0.825 & Yes \\
\hline & PGFI & Greater than 0.5 (Note 3) & 0.736 & Yes \\
\hline & $\mathrm{CN}$ & Greater than 200 & 249 & Yes \\
\hline
\end{tabular}

Note 1: Bagozzi and Yi (1988)

Note 2: Hair et al. (2010)

Note 3: Mulaik, James, Van Alstine, Bennett, Lind and Stilwell (1989)

\section{Evaluation of goodness-of-fit index of overall model}

As shown in Table 6, normalized regression weighting factors (factor loadings) of all parameters are between 0.040 and 0.898 . No weighting factor was over or too close to 1 . Standard errors were between 0.028 and 0.193 . No standard error was too big. All variances of measurement error were positive, ranging from 0.080 to 0.309 . These results confirmed that the model did not violate the test estimated (Hwang, 2015). Results of absolute goodness of fit index are shown in Table 6. All indices except Chi-square value passed the criteria for the model to be acceptable. Chi-square value is usually influenced by the number of samples. Chen and Wang (2010) have argued that researchers do not necessarily have to care too much about this index. They can even replace it with Chi-square degree of freedom. The Chi-square value in this study was 1332.05 with significance $(p=0.000)$, indicating that the goodness-of-fit of the model and the data were not good. However, the ratio of Chi-square value and the degree of freedom of this study was 4.658 , reaching the standard value. This indicates that the goodness-of-fit of the model and the data were still acceptable. Since most absolute goodness-of-fit indices passed the standards, the model was acceptable. Incremental goodness-of-fit index showed that all indices were greater than 0.9 . This means that the overall performance of the model is still within acceptable range. In the parsimony goodness-of-fit index, all indices passed the standards. Overall, these three types of indices showed that this model had good fitness.

\section{Model parameter estimation test (Path analysis of potential variables)}

$\mathrm{Yu}(2006)$ has argued that the most important concern is whether path relationships between potential variables proposed by the research model can be supported by empirical data regardless whether a structural model is fit. In order to be considered as fit, a structural model must meet the following three requirements: (1) All signs of the path coefficients between potential variables, whether positive or negative, must be the same as the direction assumed and expected by the researcher; (2) The estimated parameter value of path relationship (critical ratio value) must be statistically significant (the absolute value of $t$ is greater than $1.96 \mathrm{e}$ ); and (3) $\mathrm{R}^{2}$ (factor loading squared) of each Structural Equation Modeling (SEM) must be significant $(p<0.05)$. Detailed parameter estimate situations of the overall model in this study are shown in Table 7. Estimated values of various parameters are described as shown in Table 7. 
Table 7. Estimated values of various parameters of the overall model

\begin{tabular}{|c|c|c|c|c|c|c|c|c|}
\hline \multicolumn{3}{|c|}{ Parameter } & \multirow{2}{*}{$\begin{array}{c}\begin{array}{c}\text { Factor } \\
\text { Loading }\end{array} \\
.764^{\star}\end{array}$} & \multirow{2}{*}{$\begin{array}{c}\begin{array}{c}\text { Standard } \\
\text { Error }\end{array} \\
.227 \\
\end{array}$} & \multirow{2}{*}{$\begin{array}{c}\text { t value } \\
9.918 \\
\end{array}$} & \multirow{2}{*}{$\begin{array}{c}\begin{array}{c}\text { Error } \\
\text { Variance }\end{array} \\
.143^{\star} \\
\end{array}$} & \multirow{2}{*}{$\begin{array}{c}\mathbf{t} \text { value } \\
18.848 \\
\end{array}$} & \multirow{2}{*}{$\begin{array}{l}\mathbf{R}^{\mathbf{2}} \\
.583 \\
\end{array}$} \\
\hline Design Literacy & $\leftarrow$ & Professional Competency & & & & & & \\
\hline Design Theory & $\leftarrow$ & Professional Competency & $.708^{\star}$ & .242 & 9.665 & $.214^{\star}$ & 19.731 & .501 \\
\hline Operational Practice & $\leftarrow$ & Professional Competency & $.724^{*}$ & .268 & 9.662 & $.239^{\star}$ & 19.496 & .525 \\
\hline Design Application & $\leftarrow$ & Professional Competency & $.868^{*}$ & .279 & 10.032 & $.100^{*}$ & 14.577 & .754 \\
\hline Design Planning & $\leftarrow$ & Professional Competency & $.761^{\star}$ & .250 & 9.899 & $.175^{\star}$ & 18.878 & .579 \\
\hline Innovation Generation & $\leftarrow$ & Innovation Competency & $.857^{\star}$ & .029 & 35.01 & $.114^{\star}$ & 16.998 & .735 \\
\hline Innovation Promotion & $\leftarrow$ & Innovation Competency & $.900^{\star}$ & .028 & 37.6227 & $.086^{\star}$ & 14.172 & .810 \\
\hline Innovation Realization & $\leftarrow$ & Innovation Competency & $.862^{*}$ & .030 & 35.0916 & $.125^{\star}$ & 16.853 & .744 \\
\hline Interdisplinary Ability & $\leftarrow$ & Professional Competency & $.598^{\star}$ & .218 & 8.772 & - & - & - \\
\hline Team Cohesion & $\leftarrow$ & Professional Competency & $.151^{*}$ & .101 & 4.023 & - & - & - \\
\hline Social Skills & $\leftarrow$ & Professional Competency & $.430^{*}$ & .208 & 8.159 & - & - & - \\
\hline Social Skills & $\leftarrow$ & Interdisplinary Ability & $.260^{*}$ & .030 & 6.351 & - & - & - \\
\hline Team Cohesion & $\leftarrow$ & Interdisplinary Ability & $.073^{\star}$ & .026 & 2.378 & - & - & - \\
\hline Innovation Competency & $\leftarrow$ & Interdisplinary Ability & $.187^{\star}$ & .027 & 6.115 & - & - & - \\
\hline Innovation Competency & $\leftarrow$ & Social Skills & .071 & .079 & 1.108 & - & - & - \\
\hline Team Cohesion & $\leftarrow$ & Social Skills & $.756^{*}$ & .226 & 9.729 & - & - & - \\
\hline Innovation Competency & $\leftarrow$ & Team Cohesion & $.402^{*}$ & .074 & 5.683 & - & - & - \\
\hline Innovation Competency & $\leftarrow$ & Professional Competency & $.329 *$ & .129 & 7.227 & - & - & - \\
\hline Professional Competency & & & - & - & - & $.039 * 1$ & 5.014 & - \\
\hline Social Skills & & & - & - & - & $.130 * 2$ & 10.830 & .387 \\
\hline Interdisplinary Ability & & & - & - & - & $.258^{* 3}$ & 11.620 & .358 \\
\hline Team Cohesion & & & - & - & - & $.057^{\star 4}$ & 8.712 & .802 \\
\hline Innovation Competency & & & - & - & - & $.086^{\star 5}$ & 13.031 & .728 \\
\hline
\end{tabular}

* Indicates significant at $p<0.05$

- Indicates no estimated value.

1: Indicates variance of professional competency; 2, 3, 4, and 5 indicate structural error of social skills capability, interdisplinary ability, team cohesion, and innovation competency, respectively

Table 8. Path relationship test table

\begin{tabular}{|c|c|c|c|c|c|c|}
\hline Hypothesis & & Path & & $\begin{array}{l}\text { Hypothetical } \\
\text { Relationship }\end{array}$ & $\begin{array}{c}\text { Path Coefficient } \\
\text { (t Value) }\end{array}$ & $\begin{array}{l}\text { Hypothesis Is } \\
\text { True or False }\end{array}$ \\
\hline 1 & Professional Competency & $\rightarrow$ & Interdisplinary Ability & Positive & $0.547^{\star \star \star}(8.772)$ & True \\
\hline 2 & Professional Competency & $\rightarrow$ & Social Skills & Positive & $0.389^{* \star \star}(4.326)$ & True \\
\hline 3 & Professional Competency & $\rightarrow$ & Team Cohesion & Positive & $0.089(1.524)$ & False \\
\hline 4 & Professional Competency & $\rightarrow$ & Innovation Competency & Positive & $0.271^{\star * *}(4.311)$ & True \\
\hline 5 & Interdisplinary Ability & $\rightarrow$ & Social Skills & Positive & $0.273^{\star \star \star}(3.666)$ & True \\
\hline 6 & Interdisplinary Ability & $\rightarrow$ & Team Cohesion & Positive & $0.061(1.129)$ & False \\
\hline 7 & Interdisplinary Ability & $\rightarrow$ & Innovation Competency & Positive & $0.235^{\star \star \star}(4.484)$ & True \\
\hline 8 & Social Skills & $\rightarrow$ & Innovation Competency & Positive & $0.130(0.776)$ & False \\
\hline 9 & Social Skills & $\rightarrow$ & Team Cohesion & Positive & $0.840^{\star \star \star}(7.771)$ & True \\
\hline 10 & Team Cohesion & $\rightarrow$ & Innovation Competency & Positive & $0.397^{*}(2.221)$ & True \\
\hline \multicolumn{7}{|c|}{${ }^{*} p<0.05,{ }^{* *} p<0.01,{ }^{* \star *} p<0.001$} \\
\hline
\end{tabular}

\section{Test of hypotheses}

Based on results of empirical analysis and test, this study constructed the relationship model path diagram of professional competency, interdisplinary ability, social skills, team cohesion, and innovation as shown in Figure 4. In the figure, solid lines, dotted lines, and numerical values next to lines represent significant paths after the test, non-significant paths, and path coefficients, respectively. Values of $t$ are shown in brackets. Based on results of empirical analysis, this study carried out hypothesis test. Results are shown in Table 8. Using these ten-path relationships among five dimensions estimated by SEM (normalized coefficient value was used for each path), this study verified that, among hypotheses $1 \sim 10$ of this study's model, seven hypotheses achieved significant level of $\alpha=0.05$, with path coefficient value of "social skills " to "team cohesion" being the highest at 0.840 . 


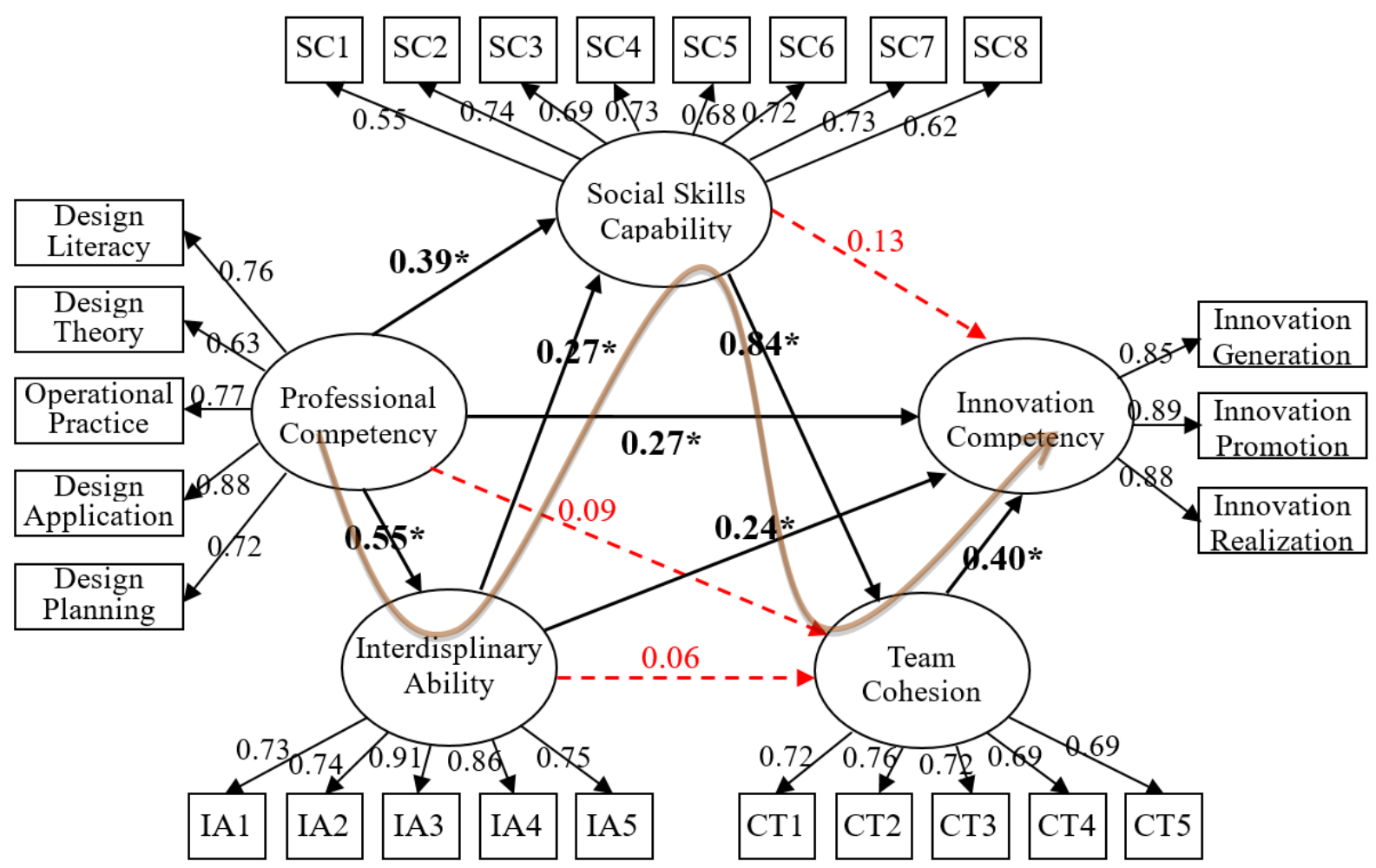

Figure 4. SEM hierarchical effect path diagram

\section{Analysis of influential effects among the five variables}

The following findings were obtained from the above analysis. When using professional competency of students enrolled in design programs as a benchmark, innovation competency is influenced by social skills, interdisplinary ability, and team cohesion in four stages. First, professional competency not only can directly influence innovation competency, but also can directly influence social skills and interdisplinary ability. Its influence on interdisplinary ability and social skills is higher than that on innovation competency. Thus, students who have better professional competency also have better interdisplinary behaviors and social status. Second, a student's professional competency influences his interdisplinary ability and social skills. A student's interdisplinary ability and social skills will eventually influence his innovation competency. Third, although a student's professional competency can influence his social skills, a student's social skills cannot directly influence his innovation competency. Fourth, high individual professional competency promotes a student's ideas on seeking interdisplinary knowledge and ability, resulting in the development of social skills The higher the maturity of a student's social skills, the more likely it will trigger his willingness toward team cohesion which will eventually generate a significant influence on his innovation competency. SEM hierarchical affecting path (thick curve line) is shown in Figure 4.

In summary, the following conclusion can be obtained by connecting paths mentioned above. From professional competency as the starting point, innovation competency is further influenced through intermediate influence of interdisplinary ability, social skills, and team cohesion. This result indicates that an individual's higher professional competency is more likely to lead him to seek learning opportunities through self-initiated interdisplinary behaviors, learn and conduct social communication with others in heterogeneous groups, show good team cohesion behaviors, and ultimately generate positive and significant influence of self innovation competency.

\section{CONCLUSIONS AND SUGGESTIONS}

In the process of cultivating design talents, design professional competency is the basis of all abilities of design talents. It is also regarded as an important benchmark of innovation competency by design talents. In designed and planned innovation process, besides professional competency, various social factors such as interdisplinary ability, social skills, and team cohesion are also important. The finding of this study can be summarized as follows:

1. Professional competency significantly influences interdisplinary ability $\left(0.55^{*}\right)$, social skills $\left(0.39^{*}\right)$, and innovation competency $\left(0.27^{*}\right)$ simultaneously. Among them, the influence of professional competency on 
interdisplinary ability is the strongest. Interdisplinary ability could also influence social skills $\left(0.27^{*}\right)$ and innovation $\left(0.24^{*}\right)$, with its influence effect on social skills being stronger. Social skills could also significantly influence team cohesion $\left(0.84^{*}\right)$ while team cohesion could significantly influence innovation competency $\left(0.40^{*}\right)$.

2. Specifically, when considering these ability variables at the same time, the major effect path is professional competency influencing interdisplinary ability, followed by interdisplinary ability influencing social skills, social skills influencing team cohesion, and team cohesion influencing innovation competency. These indirect and hierarchical influencing effects fully reflect that innovation competency of design talents is based on deep professional competency while design professional competency will fully play out through interdisplinary ability when serving and assisting various types of industries. Due to extension of interdisplinary behaviors, designers must also improve their social communication skills and put more effort on promoting team cohesion. Interdisplinary innovation competency will be ultimately generated only through team cohesion.

3. From this study, it is clear that design professionals generally need solid professional competency as well as interdisplinary abilities in order to effectively cooperate across their professional boundaries. They also need social skills to further communicate and build mutual trust with individuals from various professional fields. Team cohesion among members of an interdisplinary team can also be constructed through social skills of mutual understanding and communication. Innovation competency of design talents can only be fully expressed through team cohesion. From SEM hierarchical effect path results of this study, it is evident that when these abilities mentioned above are taken into account together, the play out of the innovation competency of design professionals is not affected by a single factor. Instead, it often continuously evolves and develops through interaction of multiple factors. This also echoes the description proposed by Bandura (1989) that in the process of interaction and exchange, benefits of individual factors may change, transform, or even disappear.

\section{REFERENCES}

Amabile, T. M. (1988). A Model of Creativity and Innovation in Organizations, in Staw, B. M. \& Cummings (Eds.). Research in Organizational Behavior, 10(1), 123-167.

Amabile, T. M., Conti, R., Lazenby, J., \& Herron, M. (1996). Assessing the work environment for creativity. Academy of Management Journal, 39(5), 123-167. https:/ / doi.org/10.5465/256995

Ay, N., \& Sung, Y. (2010). Aesthetic Economy Slows Taiwan 's Small and Medium - sized Enterprises to Construct Soft Power. Journal for SME Development, 16, 209-222.

Bandura, A. (1989). Social foundations of thought and action: A social cognitive theory. Englewood Cliffs, N. J.: PrenticeHall.

Bandura, A. (1997). Self efficacy: The exercise of control. New York: W.H. Freeman.

Bandura, A. (2001). Social cognitive theory: An agentic perspective. Annual review of psychology, 52(1), 1-26. https:// doi.org/10.1146/annurev.psych.52.1.1

Basadur, M., \& Hausdorf, P. A. (1996). Measuring divergent thinking attitudes related to creative problem solving and innovation management. Creativity Research Journal, 9(1), 21-32. https://doi.org/10.1207/s15326934crj0901_3

Calantone, R. J., \& Stanko, M. A. (2007). Drivers of Outsourced Innovation: An Exploratory Study. Product Development \& Management Association, 24, 230-241. https:/ / doi.org/10.1111/j.1540-5885.2007.00247.x

Cefis, E., \& Marsili, O. (2006). Survivor: The role of innovation in firms' survival. Research Policy, 35(5), 626-641. https://doi.org/10.1016/j.respol.2006.02.006

Chen, K. Y., \& Wang, C. H. (2010). Statistical Analysis Practice: Application of SPSS \& AMOS. Taipei: Wunan Press.

Chen, L. A. (2005). Creative Thinking Strategies \& Skills. Bulletin of Educational Resources and Research, 30, 201-221.

Chen, S. Z., \& Huang, W. Z. (2006). The Art of Innovative Design. Taipei: Longxi International Book, 13-18.

Chesbrough, H., \& Crowther, A. K. (2006). Beyond high tech: early adopters of open innovation in other industries. $R$ \& D Management, 36(3), 229-236. https:/ / doi.org/10.1111/j.1467-9310.2006.00428.x

Chiou, H. (2012). Application of fuzzy composite score for scoring situational judgment tests: A integrated operation viewpoint. Quantitative Modelling in Marketing and Management. USA: World Scientific Publishing. https:/ / doi.org/10.1142/9789814407724_0013

Chiu, S. P. (2014). A Study of Students' Core Competencies and Competitive Advantage from Design Colleges (Unpublished doctoral dissertation). National Yunlin University of Science and Technology, Taiwan.

Cohen, M. (1995). When People Get Out of the Box: New Relationships, New Systems, In Howard A (Ed.), the changing nature of work. San Francisco: Jossey-Bass, 365-410.

Craft, A., Jeffrey, B., \& Leibling, M. (Eds.). (2001). Creativity in education. A\&C Black. 
Drucker, P. F. (1998). The discipline of innovation. Harvard business review, 76(6), 149-157. https:/ / doi.org/10.1002/1t1.40619980906

Fagerberg, J., Mowery, D. C., \& Nelson, R. R. (2005). The Oxford handbook of innovation. New York: Oxford University Press. https:/ / doi.org/10.1093/oxfordhb/9780199286805.001.0001

Fornell, C., \& Larcker, D. F. (1981). Evaluating structural equation models with unobservable variables and measurement error. Journal of marketing research, 39-50. https:/ / doi.org/10.1177/002224378101800104

Hagel, J., \& Brown. J. S. (2005). The Only Sustainable Edge: Why Business Strategy Depends on Productive Friction and Dynamic Specialization. Boston: Harvard Business School Press.

Hair, J. F., Black, W. C., Babin, B. J., \& Anderson, R. E. (2010). Multivariate data analysis: A global perspective (7th ed.). Upper Saddle River, NJ: Pearson Prentice Hall. https:/ / doi.org/10.1016/j.jmva.2009.12.014

Hong, P., Nahm, A. Y., \& Doll, W. J. (2004). The Role of Project Target Clarity in An Uncertain Project Environment. International Journal of Operations and Preduction Management, 24(12), 1269-1291. https:/ / doi.org/10.1108/01443570410569047

Hsiao, W. J., \& Lai, R. Y. (2010). The Impact of Social Skills and Team Context on Knowledge-flows. International Journal of Commerce and Stratege, 2(2), 109-123.

Hulsheger, U. R., Anderson, N., \& Salgado, J. F., (2009). Team-level predictors of innovation at work: a comprehensive meta-analysis spanning three decades of research. Journal of Applied Psychology, 94(5), 11281145. https://doi.org/10.1037/a0015978

Hung, S. Y., Chen, H. G., \& Yeh, P. (2006). Effectiveness of the Creativity Support Systems: An Empirical Test of the Self-Efficacy Theory. Journal of Information Management, 13(4), 1-26.

Hwang, F. M. (2015). Structural Equation Modeling (5th ed.). Taipei: Wunan Press.

Janssen, O. (2003), Innovative behaviour and job involvement at the price of conflict and less satisfactory relations with co-workers. Journal of Occupational and Organizational Psychology, 76, 347-364. https:// doi.org/10.1348/096317903769647210

Jeffrey, B., \& Craft, A. (2004). Teaching creatively and teaching for creativity: distinctions and relationships. Educational studies, 30(1), 77-87. https:/ / doi.org/10.1080/0305569032000159750

Kerr, B., \& Gagliardi, C. (2003). Measuring creativity in research and practice. In S. J. Lopez \& C. R. Snyder (Eds.) Positive Psychological Assessment: A Handbook of Models and Measures. Washington D.C: American Psychological Association. https:/ / doi.org/10.1037/10612-010

Kimble, C., Grenier, C., \& Goglio-Primard, K. (2010). Innovation and knowledge sharing across professional boundaries: Political interplay between boundary objects and brokers. International Journal of Information Management, 30, 437-444. https:// doi.org/10.1016/j.ijinfomgt.2010.02.002

Kodama, M. (2007). Innovation through Boundary Management - A Case Study in Reforms at Matsushita Electric. Technovation, 27, 15-29. https:// doi.org/10.1016/j.technovation.2005.09.006

Kodama, M. (2009). Boundaries Innovation and Knowledge Integration in the Japanese Firm. Long Range Planning, 42(4), 463-494. https:// doi.org/10.1016/j.lrp.2009.08.001

Luh, D. B., \& Lu, C. C. (2012). Co-competition based Recruitment Approach. Journal of Design, 17(1), 1-24.

Morgeson, F. P., Reider, M. H., \& Campionk, M. A. (2005). Selecting Individuals in Team Settings: the Importance of Social Skills, Personality Characteristics, and Teamwork Knowledge. Personnel Psychology, 58(3), 583-612. https://doi.org/10.1111/j.1744-6570.2005.655.x

Robbins, S. P. (2001). Organizational behavior, 14/E. Pearson Education India.

Stark, J. S., Lowther, M. A., \& Hagerty, B. M. K. (1986). Responsive professional education: Balancing outcomes and opportunities. Washington, DC: ASHE

Teigland, R., \& Wasko, M. (2003). Integrating Knowledge Through Information Trading: Examining the Relationship Between Boundary Spanning Communication and Individual Performance. Decision Sciences, 34(2), 261-287. https:/ / doi.org/10.1111/1540-5915.02341

Tien, C. T., \& Lu, T. Y. (2005). The relationships of psychological contract and innovative behaviors: Cognitive style as a moderator. Paper presented at the 2005 Health Management Conference, Taiwan.

Tjosvold, D. (1988). Cooperative and competitive dynamics within and between organizational units. Human Relations, 41(6), 425-436. https:/ / doi.org/10.1177/001872678804100601

Wang, L. Y., Chang, C. N., \& Chiang, S. C. (2014, Sep). Network-based Recommendation Game for Increasing the Response Rate of Web Survey on Higher Education. Paper presented at the 2013 European Conference on Educational Research, Porto, Portugal. 
Wen, L. Y., \& Chen, M. H. (2008). A Study of the Influence on Organizational Innovation Climate and Employee Engagement to individual Innovative Behavior. Paper presented at the 2016 Health Management Conference, Taiwan.

Woodman, R. W., Sawyer, J. E., \& Griffin, R. W. (1993). Psychographics and creativity. Journal of Advertising, 2(March), 32-35. https:/ / doi.org/10.1080/00913367.1973.10672482

Wu, M. C., Chang, W. L., \& Chen, C. C. (2012). Retrospect and Prospect of Design Education in Taiwan. Taiwan Education Review, 674, 77-80.

Yu, M. N. (2006). Latent Variable Models: The Application of SIMPLIS. Taipei: H-EDU Press.

\section{http://www.ejmste.com}

